\title{
Relationship between Level of Knowledge of Childbearing Age Women About Cervical Cancer and Behavior of Preventing Cervical Cancer in Mayamuk District, Sorong Regency
}

\author{
Sunaeni, S.ST, M.Keb \\ Lecturer of Politeknik Kesehatan Kemenkes Sorong
}

\begin{abstract}
Cervical cancer is the second highest cancer prevalence in women in the world. Cervical cancer usually occurs among women aged 30-50 years. In Indonesia, an estimated 40,000 new cases of cervical cancer each year. Women with cervical cancer mostly late for medical management because lack of knowledge about cervical cancer that resulted in late medical examination.

The research design used was correlational analytic with cross sectional approach. The population was women of childbearing age from 20-35 years old in Mayamuk District, Sorong Regency with a total of 66 respondents who were taken by using total sampling. Data collection instruments used were questionnaires. The data analysis used was Chi Square test with $5 \%$ level of significance.

From the research results it is obtained that $41 \%$ (27 respondents) have insufficient knowledge, and 55\% (36 respondents) have negative behavior. From the analysis with Chi Square test with 5\% level of significance it was obtained that the count $X^{2}(20.602)>X^{2}$ table (5.99), meaning that there is a relationship between the knowledge of women of childbearing age about cervical cancer with the behavior of preventing cervical cancer in the Mayamuk District, Sorong Regency.

It is expected that health workers will further enhance the provision of counseling to the community and optimize prevention programs against cervical cancer and the community can further enhance their knowledge of early prevention of cervical cancer especially women in childbearing age.
\end{abstract}

Keywords: Knowledge of women of childbearing age, cervical cancer, prevention behavior

\section{Introduction}

Cervical cancer ranks second after breast cancer as the most common cancer suffered by Indonesian women. In Indonesia an estimated 40 thousand new cases of cervical cancer are found each year ${ }^{1}$. Ignorance of the community and low socioeconomic status are the main obstacles for having a check $u^{2}$. In a preliminary study conducted by researchers in the Mayamuk District of Sorong Regency, out of 20 women of childbearing age, there were 16 women (80\%) had less knowledge about cervical cancer, 3 women (15\%) had fair level of knowledge and only 1 women (5\%) who have good level of knowledge. And out of the 20 women, 9 (45\%) have negative behavior in preventing cervical cancer.
This study aims to determine the relationship between the level of knowledge of women of childbearing age about cervical cancer with cervical cancer prevention behavior in Mayamuk District, Sorong Regency in 2014.

\section{Materials and Method}

The study used a correlational analytic design with a cross sectional approach. The population is women of childbearing age aged 20-35 years in Mayamuk District, Sorong Regency with a total of 66 respondents that were chosen using Total Sampling. Data collection instruments using a questionnaire. The data analysis used was Chi Square test with 5\% level of significance. 


\section{Results}

\section{A. General data}

\section{Characteristics of Respondents According to Level of Education}

Table 1 Characteristics of Respondents Based on Level of Education in Mayamuk District, Sorong Regency in 2014

\begin{tabular}{|c|c|c|c|}
\hline No & Level of Education & f & $\%$ \\
\hline 1 & Not Graduate Elementary School & 7 & $11 \%$ \\
\hline 2 & Elementary School & 21 & $32 \%$ \\
\hline 3 & Junior High School & 18 & $27 \%$ \\
\hline 4 & Senior High School & 16 & $24 \%$ \\
\hline 5 & Higher Education & 4 & $6 \%$ \\
\hline & Total & 66 & $100 \%$ \\
\hline
\end{tabular}

From table 1, the result shows that out of the 66 respondents, majority of 32\% ( 21 respondents) were elementary school graduate.

\section{The Source of Information about Cervical Cancer}

Table 2 The Source of Information about Cervical Cancer in Mayamuk District, Sorong Regency in 2014.

\begin{tabular}{|l|l|l|l|}
\hline No & Source of Information & f & $\%$ \\
\hline 1 & Magazine & 2 & $4 \%$ \\
\hline 2 & Health Personnel & 40 & $60 \%$ \\
\hline 3 & Radio & 0 & $0 \%$ \\
\hline 4 & Television & 24 & $36 \%$ \\
\hline & Total & 66 & $100 \%$ \\
\hline
\end{tabular}

From table 2 majority of respondents or $60 \%$ (40 respondents) obtain information from health workers.

\section{B. Special Data}

\section{Characteristics of Respondents Based on Knowledge about Cervical Cancer}


Table 3 Characteristics of Respondents Based on Level of Knowledge About Cervical Cancer in Mayamuk District, Sorong Regency in 2014

\begin{tabular}{|l|l|l|l|}
\hline No & Level of Knowledge & $\mathbf{f}$ & $\%$ \\
\hline 1 & Good & 20 & $30 \%$ \\
\hline 2 & Fair & 19 & $29 \%$ \\
\hline 3 & Low & 27 & $41 \%$ \\
\hline & Total & 66 & $100 \%$ \\
\hline
\end{tabular}

From table 3, the results show that the majority of respondents or 41\% (27 respondents) have low level of knowledge, and lowest presentage or 29\% (19 respondents) have fair level of knowledge.

\section{Characteristics of Respondents Based on Behavioral Prevention of Cervical Cancer}

Table 4 Characteristics of Respondents Based on Preventive Behavior of Cervical Cancer in Mayamuk District, Sorong Regency in 2014

Chi-Square Tests

\begin{tabular}{|l|r|r|r|}
\hline & Value & df & \multicolumn{1}{|c|}{$\begin{array}{c}\text { Asymp. Sig. } \\
\text { (2-sided) }\end{array}$} \\
\hline Pearson Chi-Square & $20,602^{\mathrm{a}}$ & 2 &, 000 \\
Likelihood Ratio & 22,302 & 2 &, 000 \\
Linear-by-Linear & 19,792 & 1 &, 000 \\
Association & 66 & & \\
N of Valid Cases & & & \\
\hline
\end{tabular}

a. 0 cells $(, 0 \%)$ have expected count less than 5 . The minimum expected count is 8,64 .

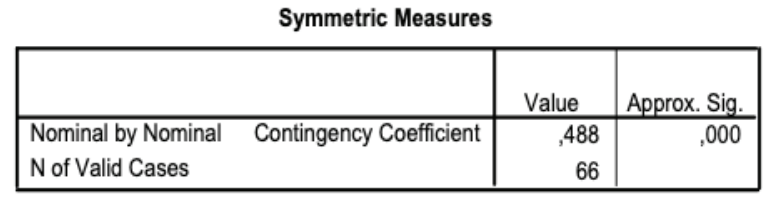

a. Not assuming the null hypothesis.

b. Using the asymptotic standard error assuming the null hypothesis.

\begin{tabular}{|l|l|l|l|}
\hline No & $\begin{array}{l}\text { Preventive Behavior of } \\
\text { Cervical Cancer }\end{array}$ & $\mathbf{f}$ & $\mathbf{\%}$ \\
\hline 1 & Positive behavior & 30 & 45 \\
\hline 2 & Negative behavior & 36 & 55 \\
\hline Total & 66 & 100 \\
\hline
\end{tabular}

Based on table 4, it indicates that out of the 66 respondents, the highest percentage or 55\% (36 respondents) had negative behaviors towards cervical cancer prevention.

\section{Data analysis}

Table 5 Cross Tabulation of Level of Knowledge of Women of Childbearing Age about Cervical Cancer with Preventive Behavior of Cervical Cancer in Mayamuk District, Sorong Regency in 2014.

\begin{tabular}{|c|c|c|c|c|c|c|c|}
\hline \multirow{3}{*}{ No } & \multirow{3}{*}{$\begin{array}{l}\text { Level of } \\
\text { Knowledge } \\
\text { of Cervival } \\
\text { Cancer }\end{array}$} & \multicolumn{4}{|c|}{$\begin{array}{l}\text { Preventive Behavior of } \\
\text { Cervical Cancer }\end{array}$} & \multirow{2}{*}{\multicolumn{2}{|c|}{ Total }} \\
\hline & & \multicolumn{2}{|c|}{ positive } & \multicolumn{2}{|c|}{ negative } & & \\
\hline & & f & $\%$ & f & $\%$ & f & $\%$ \\
\hline 1 & Good & 17 & 25 & 3 & 5 & 20 & 30 \\
\hline 2 & Fair & 8 & 12 & 11 & 17 & 19 & 29 \\
\hline 3 & Low & 5 & 8 & 22 & 33 & 27 & 41 \\
\hline & & 30 & 45 & 36 & 55 & 66 & 100 \\
\hline
\end{tabular}

Based on table 5, it shows that out of 20 respondents who had good level of knowledge, 17 respondents had positive behavior and 3 respondents had negative behavior. In the other hand, out of 27 respondents had low level of knowledge, 5 respondents had positive behavior and 22 respondents had negative behavior.

Chi Square statistical test was performed to analyze the relationship of level of knowledge women in childbearing age with cervical cancer prevention behavior at $(\alpha)=0.05$.

The data analysis resulted the $X^{2}$ count results obtained $=20.602$ and $X^{2}$ tables $=5.99$. Therefore $X^{2}$ count $>X^{2}$ table means that there is a relationship between the level of knowledge of childbearing age women about cervical cancer with the preventive behavior of cervical cancer.

\section{Discussion}

From the findings of the research shows that mostly 
$41 \%$ (27 respondents) have low level of knowledge, and 55\% (36 respondents) have negative behavior. From the analysis with Chi Square test with 5\% level of significance, it was obtained that the count $X^{2}$ (20.602)> $X^{2}$ table (5.99), means that there is a relationship between the level of knowledge of women of childbearing age about cervical cancer with the preventive behavior of cervical cancer in the Mayamuk District, Sorong Regency.

In Rogers research ${ }^{2-4}$ Notoatmodjo, states that behavior based on knowledge will be more lasting than behavior that is not based on knowledge. Knowledge will affect individual behavior which will further influence community behavior towards healthy promoting behavior. It is especially the knowledge about cervical cancer and its prevention. In addition to knowledge, level of education is also an internal factor that influences one's knowledge and behavior. Higher level of education of the person enable their ability to receive information obtained from various sources such as through magazines, television, radio, and from health workers easier ${ }^{5-11}$.

From the results of this study it can be seen that there is no gap between theory and research results. Because the results of the study indicate that the source of information actually affects the knowledge of women of childbearing age who majority of them never obtain information about cervical cancer. Knowledge is also influenced by level of education as supported by finding that majority of them were elementary school graduate $^{12-15}$.

While in terms of behavior, women of childbearing age in preventing cervical cancer are mostly having negative behaviors. The cause of this is the lack of knowledge that is not sufficient to support good behavior. Even though they lack knowledge, they are expected not to have negative behavior as well. ${ }^{16-18}$

\section{Conclusion}

There is a relationship between the level of knowledge of women of childbearing age about cervical cancer with the behavior of cervical cancer prevention in Mayamuk District, Sorong Regency in 2014

\section{Suggestions}

\section{For Respondents}

It is expected that women of childbearing age make the effort to improve their knowledge and information about cervical cancer through various mass media and electronic media (magazines, newspapers, television, etc.) and from health workers, so that they better understand cervical cancer and its prevention.

\section{For Health Agencies}

Information about cervical cancer and its prevention programs must be disseminated more broadly and optimally. Health workers further enhance the provision of counseling to the community and optimize prevention programs against cervical cancer, especially in women of childbearing age.

\section{For the Wider Community}

The public is expected to improve their knowledge more broadly by participating in counseling programs and examinations for early detection of cervical cancer that are given and programmed by the government and health workers.

Ethical Clearance: from university ethical committee

Source of Funding : This publication was supported by the Health Polytechnic Ministry of Health, Sorong, Indonesia.

\section{Conflict of Interest : Nil}

\section{References}

1. Rasjidi, I. Deteksi Dini dan Pencegahan Kanker pada Wanita (Early Detection and Prevention of Cancer in Women). Yogyakarta: Nuha Medika. 2009.

2. Rasjidi, I. Manual Prakanker Serviks (Cervical Pre-Cancer Manual). Jakarta: CV Sagung Seto. 2008.

3. Notoatmodjo, S. Kesehatan Masyarakat Ilmu dan Seni (Public Health Sciences and Arts). 2007. Jakarta: Rineka Cipta.

4. Notoatmodjo, S. Promosi Kesehatan dan Ilmu Perilaku (Health Promotion and Behavioral Sciences). Jakarta: Rineka Cipta. 2007.

5. Notoatmodjo, S. Metodologi Penelitian Kesehatan 
(Health Research Methodology). Jakarta: Rineka Cipta. 2010.

5. Arikunto. S. Prosedur Penelitian Suatu Pendekatan Praktik (Research Procedure A Practical Approach). Jakarta : Rineka Cipta. 2010.

6. Aziz, M.F. Panduan Pelayanan Medik:Model Interdisipin Penatalaksanaan Kanker Serviks dengan Gangguan Ginjal (Guidelines for Medical Services: Interdisciplinary Model of Management of Cervical Cancer with Kidney Disorders). Jakarta: EGC. 2008.

7. Azwar. Sikap Manusia Teori dan Pengukurannya Edisi ke-2 (The Human Attitude Theory and Its Measurement 2nd Edition). Jakarta : Pustaka Pelajar. 2009.

8. Benson,dkk. Buku Saku Obstetri dan Ginekologi (Handbook of Obstetrics and Gynecology). Jakarta: EGC. 2009.

9. Getsway, N. Konsep Perilaku Manusia (The Concept of Human Behavior). repository. usu. ac. id/ bitstream/123456789/17871/.../Chapter\%20II. 2010. pdf. 9 November 2013.

10. Hidayat, A.A. Metode Penelitian Kebidanan dan Teknik Analisis Data (Midwifery Research Methods and Data Analysis Techniques). Jakarta: Salemba Medika. 2007.

11. Prawirohardjo, S. Ilmu Kandungan (Gynecology). Jakarta:Yayasan Bina Pustaka, 2004.
12. Riyanto, A. Aplikasi Metodologi Penelitian Kesehatan (Health Research Methodology Application). Yogyakarta: Nuha Medika. 2011.

13. Syam, A., Palutturi, S., Djafar, N., Budu, Astuti, N., Thaha, A.R. Micronutrients, academic performance and concentration of study: A literature review. International Journal of Applied Business and Economic Research, 2016; Volume 14, Issue 5, 2016, Pages 2831-2843

14. Patimah, S., Arundhana, A.I., Mursaha, A., Syam, A. Development of foxtail millet and flying fish flour-based cookies as functional food, Current Research in Nutrition and Food Science, 2019. Volume 7, Issue 2, August 2019, Pages 504-516

15. Mallongi, A.,Safiu, D., Amqam, H., Syam, A., Hatta, M., Sutarti, T., Abdul, M., Siyoto, S., Apollo., Modelling of $\mathrm{SO}_{2}$ and $\mathrm{CO}$ pollution due to industry PLTD emission Tello in 2 Makassar Indonesia. Journal of Engineering and Applied Sciences Volume 14, Issue 2, 2019, Pages 634-640

16. Jafar, N., Indriasari, R., Syam, A., Kurniati, Y., Exploration on adolescent knowledge related metabolic syndrome (METS). Indian Journal of Public Health Research and Development 2018. Volume 9, Issue 6, June 2018, Pages 263-266

17. Ulfa $M$, et al. Effect of education media on improvement visual acetate acid inspection at Sudiang community health center. Enferm Clin. 2020. https://doi.org/10.1016/j.enfcli.2019.10.118 